\title{
Energetic cost of gonad development in Calanus finmarchicus and $C$. helgolandicus
}

\author{
Catherine Rey-Rassat $^{1, *}$, Xabier Irigoien ${ }^{2, * *}$, Roger Harris $^{2}$, François Carlotti ${ }^{3}$ \\ ${ }^{1}$ Université Pierre et Marie Curie (Paris VI), Station Zoologique, ESA 7076, CNRS/INSU, BP 28, 06230 Villefranche-sur-mer, France \\ ${ }^{2}$ Plymouth Marine Laboratory, Prospect Place, Plymouth PL1 3DH, United Kingdom \\ ${ }^{3}$ Laboratoire d'Océanographie Biologique, CNRS, Université Bordeaux 1, UMR 5805, 2 rue du Professeur Jolyet, 33120 Arcachon, France
}

\begin{abstract}
The energetic cost of moulting and gonad maturation from Stage CV to adult has been estimated in the copepods Calanus helgolandicus and C. finmarchicus. For both species, this was done by following 2 laboratory-reared cohorts, one reared at a high food concentration (Cohort $\mathrm{H}$ ) and the other at a comparatively lower food concentration (Cohort L). The 2 cohorts of each species were maintained at a constant temperature $\left(15^{\circ} \mathrm{C}\right.$ for $C$. helgolandicus and $\sim 8^{\circ} \mathrm{C}$ for C. finmarchicus). The wax ester (WE) content was estimated in late $\mathrm{CV}$ and new moulted females, on the day when approximately 40 to $50 \%$ of the individuals of the cohort had moulted to adulthood. Copepodite Stage CV in Cohort H had accumulated much more WE than those in Cohort L $(2.2$ and 1.4 times more in the case of $C$. helgolandicus and $C$. finmarchicus, respectively). However, for both species, the amount of WE catabolized during the moulting of the $\mathrm{CV}$ stage from Cohort $\mathrm{H}$ is very similar to that of $\mathrm{CV}$ from Cohort $\mathrm{L}$. In both cohorts, it is equivalent to $\sim 20 \mu \mathrm{gC}$ for C. helgolandicus and $\sim 40 \mu \mathrm{g} C$ for $C$. finmarchicus. Because of the difficulty of properly estimating the WE content at the end of $\mathrm{CV}$, we consider that our values are underestimates, and a subsequent analysis, which considers the upper range of the WE content estimated at the end of $\mathrm{CV}$, suggests values up to $\sim 30 \mu \mathrm{gC}$ for $C$. helgolandicus and $\sim 70 \mu \mathrm{g}$ C for C. finmarchicus. This WE catabolism is mainly due to gonad maturation, which occurred at this time, although part of it is also due to the loss of the exoskeleton and the energy required for the moulting process. We propose that the values obtained in this study can be used as a threshold to determine those animals that can descend for overwintering and those that have to remain at the surface, because the CVs with a WE storage below the threshold value will not be able to support the additional energetic costs linked to the overwintering strategy. Therefore, in the field, the percentage of copepods going into overwintering would be a consequence of the growth conditions. The WE threshold is likely to vary with temperature (with a lower value at higher temperature) since metabolism is more rapid at higher temperature.
\end{abstract}

KEY WORDS: Calanus helgolandicus - Calanus finmarchicus . Lipid · Gonad · Overwintering

Resale or republication not permitted without written consent of the publisher
The accumulation of stored lipids mostly during the last 3 copepodite stages is a common feature in most Calanus species (Kattner \& Krause 1987). These lipids support overwintering in deep cold waters when food is scarce at the surface (Hirche 1996a,b) and they also play a role as regulators of buoyancy (Visser \& Jónasdóttir 1999). Lipids are stored mainly as wax esters (WEs) accumulated in a sac located in the cephalosome above the gut and the gonad. Triacylglycerols, which also constitute a small part of the lipid components, are considered to be an index of recent feeding, or as an intermediate component of WE catabolism (Sargent et al. 1977, Hakanson 1984).

Calanus finmarchicus and C. helgolandicus generally dominate the zooplankton biomass in the North Atlantic; the first of these species is abundant in coastal and open ocean areas that are located mostly to the north of the Gulf Stream, whereas C. helgolandicus is distributed in the warmer waters to the south (Fromentin \& Planque 1996). In a recent study, Jónasdóttir (1999) used a model to estimate how stored lipids in $C$. finmarchicus are used in each of the energetic processes occurring during the activation and the terminal phases of diapause. However, because of the difficulties in following the growth of a cohort in detail, the cost of gonad maturation has never been measured for Calanus. In this study, we attempt to provide a first measurement under laboratory conditions of the cost of gonad formation during moulting from $\mathrm{CV}$ into adult for the 2 dominant Calanus species in the North Atlantic.

\footnotetext{
*E-mail: catherinerey@aol.com

${ }^{* *}$ Present address: AZTI, Herrera Kaia portualdea z/g, 20110 Pasaia (Gipuzkoa), Spain
} 
Materials and methods. This approach is based on laboratory rearing of both species where the sampling intensity allowed us to follow not only the change in WE storage between stages but also within the stage. In this study, we analyzed the WE content of late copepodite Stage CV and newly moulted females of $C$. helgolandicus and C. finmarchicus. For each of the species, the CV and the females came either from a cohort reared at a low food concentration (Cohort L) or a cohort reared at a high food concentration (Cohort H); the 2 cohorts were held at a constant temperature $\left(15^{\circ} \mathrm{C}\right.$ for C. helgolandicus and $\sim 8^{\circ} \mathrm{C}$ for $\mathrm{C}$. finmarchiCus). The conditions of each rearing are summarized in Table 1. For both species, WE contents were estimated indirectly by considering the oil sac volume of 30 copepods per stage. The volume was transformed into WE by: (1) multiplying it by the density of $0.86 \mathrm{~g} \mathrm{ml}^{-1}$ (Sargent \& Henderson 1986); (2) multiplying it by the ratio of the carbon content in WE of 0.78 (from Table 2.3 of Sargent \& Henderson 1986); and (3) dividing it with a conversion factor of 1.44 from the method based on the oil sac volume (from Fig. 6 of Miller et al. 1998).

We wanted to estimate the lipid catabolism that occurs during the last moulting, from $\mathrm{CV}$ to adult female. Since the lipid content increases during the development of Stage CV, we took care to determine the lipid content at the end of the stage. In fact, some authors (Gatten et al. 1980) have already attempted to estimate experimentally this energetic cost by using 2 samples of wild CVs. One of the samples was used to estimate the lipid content at time $t=0$, and the other one was incubated for $24 \mathrm{~h}$ to subsequently determine the lipid content in the females which had just moulted during the incubation period. However, in this approach, the lipid content estimated for the CV at $t=0$ is an average of the lipid contents of all the CVs which were present in the first sample, and it is certainly not a good estimate of the final lipid content of the CV just prior to moulting. Indeed, some of the CVs that were initially present in the sample were ready to moult, while others had just entered the stage. In the data we present here, we addressed this problem carefully and we estimated the final lipid content of the $\mathrm{CV}$ as accurately as possible. In the case of Calanus helgolandicus, the WE content of $\mathrm{CV}$ was the value estimated by Rey-Rassat et al. (2002a, this volume) for the day when $50 \%$ of the individuals have left $\mathrm{CV}$ and entered the adult stage. Even though this date seems to be arbitrary, it defines the end of the stage $\mathrm{CV}$ in an objective way that can be used to com- pare studies. The estimate of the WE content in the newly moulted females was not made on the same day as for CV but 1 and $3 \mathrm{~d}$ later for the Cohorts $\mathrm{H}$ and $\mathrm{L}$, respectively. In the case of $\mathrm{C}$. finmarchicus, the WE was estimated from the data on the volume of the oil sac given in Rey et al. (1999). These estimates were made on $\mathrm{CV}$ and females sampled the same day when around $40 \%$ of the individuals from both cohorts had entered the adult stage. The fact that the WE was estimated on the day when $40 \%$ of the C. finmarchicus had entered the adult stage and not $50 \%$ (as for $C$. helgolandicus) has certainly contributed a lower lipid value, but we were forced to do so since the day when $40 \%$ of the C. finmarchicus entered the adult stage was also the day when the mesocosm experiment ended.

The results on the WE contents of Stages CV and females are presented in Table 2. WE contents of Calanus helgolandicus were much lower than those in C. finmarchicus, probably due to more rapid metabolism at the higher temperature (i.e. the temperature range encountered by $C$. helgolandicus), although interspecific differences are also possible. For both species, we found that the WE content was much lower in Stage $\mathrm{CV}$ of Cohort L than in those of Cohort H. Lower lipid deposition occurred in Cohort $\mathrm{L}$ since the amount of food available for the organisms was much lower. An important fraction of the WE accumulated during Stage CV is catabolized during moulting into females, and the percentages of lipid depletion were higher in Cohort $\mathrm{L}$ than in Cohort $\mathrm{H}$, for both $\mathrm{C}$. helgolandicus (87 and $48 \%$ in Cohorts $\mathrm{L}$ and $\mathrm{H}$, respectively) and $C$. finmarchicus ( 49 and $36 \%$ in Cohorts $\mathrm{L}$ and $\mathrm{H}$, respectively). However, when we look at the absolute values of the WE catabolized during moulting, it appears that in both species the values are independent of the amount accumulated during Stage CV. In other words,

Table 1. Summary of the conditions of rearing of Calanus helgolandicus and $C$. finmarchicus (for more details see Rey-Rassat et al. 2002a and Hygum et al. 2000 respectively)

\begin{tabular}{|c|c|c|}
\hline & C. helgolandicus & C. finmarchicus \\
\hline Area of the study & $\begin{array}{l}\text { Plymouth Marine } \\
\text { Laboratory }\end{array}$ & $\begin{array}{l}\text { Raunefjord } \\
\text { (southern Norway) }\end{array}$ \\
\hline Date & Summer 1998 & Spring 1997 \\
\hline Volume of rearing & $150 \mathrm{ltank}$ & $18.5 \mathrm{~m}^{3}$ mesocosm \\
\hline Temperature & $15^{\circ} \mathrm{C}$ & $8^{\circ} \mathrm{C}^{\mathrm{a}}$ \\
\hline Food & Prorocentrum micans & $\begin{array}{l}\text { Natural microplankton } \\
\text { community }\end{array}$ \\
\hline Concentration of Cohort L & $77.5 \mu \mathrm{gC}^{-1}$ & $438 \mu \mathrm{gC} \mathrm{l}^{-1 \mathrm{a}}$ \\
\hline Concentration of Cohort $\mathrm{H}$ & $278 \mu \mathrm{gC}^{-1}$ & $790 \mu^{-12 a}$ \\
\hline \multicolumn{3}{|c|}{$\begin{array}{l}\text { a Since temperature and food concentration were fluctuating during this } \\
\text { study, these values are the averages found during the development of the } \\
\text { last } 2 \text { copepodite stages CIV and CV }\end{array}$} \\
\hline
\end{tabular}


in both Cohorts $\mathrm{L}$ and $\mathrm{H}$, the amount of WE used in the moulting and gonad maturation process is constant, and not relative to the amount previously accumulated. In the case of $C$. helgolandicus, the amount of WE used is $\sim 20$ and $\sim 40 \mu \mathrm{gC}$ for $C$. finmarchicus. This catabolism is attributed to the cost of (1) the moulting itself and (2) gonad development (Gatten et al. 1980, Hirche 1996a, Jónasdóttir 1999).

Cost of moulting itself. The energy expended during moulting is usually assumed to be low. Vidal (1980b) found a decrease in individual body carbon due to exoskeleton loss equal to between $\sim 2.8$ and $5.1 \%$ in copepodite stages of Calanus pacificus. Moulting itself may also consume energy, enhancing the catabolism of internal resources. Increased respiration and excretion are expected during moulting as this has been shown in euphausiids (Ikeda \& Mitchell 1982, Ikeda et al. 2000). The difference between the final weight of one juvenile stage (i) and the initial weight of the juvenile stage $(i+1)$ could be an index of the cost of moulting. In some of the studies in which Calanus cohorts were reared, an overlapping of the weight values of 2 successive stages was observed. Such overlapping of the weight data was observed in Rey-Rassat et al. (2002a) between CIV and CV of the Cohort L. If we consider the highest weight of the CIV (found on the last day of sampling of the stage), we found a decrease of $8.0 \mu \mathrm{g} \mathrm{C}$ and $1.0 \mu \mathrm{g} \mathrm{N}$ compared with the first values of $\mathrm{CV}$ and, in percentage terms, this corresponds to 22 and $13 \%$ weight loss, respectively. Interestingly, very similar percentages are found by using the weight data reported in the Fig. 6 of Hygum et al. (2000) for C. finmarchicus CIV reared at a low food concentration (21 and $11 \%$ of loss in carbon and nitrogen weight, respectively). Both these percentages are found by consider- ing the second to last weight value of the CIV shown in Hygum et al. (2000) and not the last one, which is very low and probably corresponds to latecomer animals (Lopez 1991, Carlotti \& Nival 1992). Indeed, the last weight value of the CIV was obtained on the day when only $2 \%$ of the individuals of the cohort were still in this stage. The percentage of weight lost during moulting of Stage CIV is rather similar in both Calanus species and seems not to be negligible. However, it may be different in other copepodite stages and, in the case of CIV, it can be due not only to moulting but also to the development of gonad tissues which starts at Stage CIV (Tande \& Hopkins 1981).

Cost of gonad development. The main part of the gonad maturation processes is recognized to occur during moulting of CV into adults (Gatten et al. 1980, Tande 1982, Runge 1984, Sargent \& Falk-Petersen 1988). It is the catabolism of a significant amount of WE that enables the synthesis of gonad tissue and the occurrence of Vitellogenesis 1 in ovocytes (Sargent \& Henderson 1986, Sargent \& Falk-Petersen 1988, Plourde \& Runge 1993, Hirche 1996a, Niehoff \& Hirche 1996). The lipid used during moulting may not be sufficient to support all the gonad maturation. In fact, Calanus finmarchicus newly moulted females which had been used to estimate the WE content were found still to be immature (see Fig. 5C in Rey et al. 1999). However, the gonadal stage of almost all those immature females was found to be G3 (following criteria described by Runge 1987), i.e. their gonad formation was well advanced. The energy required to complete the gonad development possibly came from ingestion, which increased after moulting (Rey et al. 1999, Rey-Rassat et al. 2002b). The role of ingestion of food in the completion of gonad maturation was demonstrated in previ-

Table 2. Wax ester content (in $\mu \mathrm{gC}$ ) estimated at the end of the copepodite Stage CV and at the beginning of the females for Calanus helgolandicus and C. finmarchicus. For each species, 2 cohorts were reared in mesocosms, one under low food concentration (Cohort L) and the other under high food concentration (Cohort H). Wax ester (WE) catabolized during moulting was calculated by subtracting the WE of females (F) from that of Stage CV. In the case of C. helgolandicus, the WE content was estimated at the end of the copepodite Stage CV (i.e. the day when $50 \%$ of the individuals had left the stage and entered the adult stage) and at the start of the female life-time (i.e. 1 and $3 \mathrm{~d}$ after the day when $50 \%$ of the individuals had entered the adult stage in Cohorts $\mathrm{H}$ and L, respectively). In the case of C. finmarchicus, the WE content was estimated on CV and females sampled the same day (i.e. the day when the rearing in mesocosm ended, which corresponds to the day when $40 \%$ of the individual had entered the adult stage). The numbers in brackets indicate the upper values of the WE content reached at the end of Stage CV or catabolized during moulting. These upper values were estimated from the 12 to 15 values superior to the mean values calculated from 30 measurements made on individuals collected at the end of the stage CV

\begin{tabular}{|c|c|c|c|c|c|c|c|c|}
\hline \multirow[b]{3}{*}{ Cohort L } & \multicolumn{3}{|c|}{ C. helgolandicus } & \multicolumn{5}{|c|}{ C. finmarchicus } \\
\hline & $\begin{array}{l}\text { WE of } \\
\text { CV }\end{array}$ & \multirow{2}{*}{$\begin{array}{c}\text { WE of } \\
\text { F } \\
2.8\end{array}$} & \multirow{2}{*}{$\begin{array}{c}\text { WE } \\
\text { catabolized } \\
19(28)\end{array}$} & \multicolumn{2}{|c|}{$\begin{array}{l}\text { WE of } \\
\text { CV }\end{array}$} & \multirow{2}{*}{$\begin{array}{c}\text { WE of } \\
\text { F } \\
42\end{array}$} & \multicolumn{2}{|c|}{$\begin{array}{c}\text { WE } \\
\text { catabolized }\end{array}$} \\
\hline & $22\left(31^{\mathrm{a}}\right)$ & & & 82 & (105) & & 40 & (63) \\
\hline Cohort H & $48 \quad(55)$ & 25 & $23 \quad(30)$ & 116 & $(142)$ & 74 & 42 & (68) \\
\hline
\end{tabular}


ous studies (Marshall \& Orr 1955, Tande 1982, Diel \& Tande 1992). The majority of the WE remaining after the moulting was possibly used to support the maturation of the next ovocytes (Vitellogenesis 1) or as part of their metabolism (Hirche 1996a, Rey-Rassat et al. 2002b). There is also some evidence that Calanus females (at least $C$. finmarchicus) are able to produce their first eggs (i.e. Vitellogenesis 1 and 2) entirely from their stored lipid in the absence of food (Diel \& Tande 1992, Niehoff et al. 1999, Richardson et al. 1999).

Comparison with the literature. For Calanus finmarchicus, Jónasdóttir (1999) used a model to evaluate the cost of gonad maturation and the cost of moulting to adult. These costs were equal to 70 and $8 \mu \mathrm{gC}$, respectively. Our estimate is somewhat lower (a total of $\sim 40 \mu \mathrm{g} \mathrm{C}$ including both moulting and maturation), but it is certainly underestimated because all the CVs we used had not yet reached their maximal lipid level. Also, the individuals were collected when only $40 \%$ of the CVs had moulted to the adult stage, which will have contributed to an underestimate of the WE content at the end of Stage CV. To evaluate the possible error involved, we assumed that the upper $50 \%$ values of lipid content at the end of Stage CV (upper 15 values from the original 30 values) are those representing individuals which were the closest to moult into adults. The new estimate of the WE used for moulting and maturation, by considering only these 15 upper values, were 63 and $69 \mu \mathrm{gC}$ of WE for C. finmarchicus and 28 and 30 for C. helgolandicus in Cohorts $\mathrm{L}$ and $\mathrm{H}$, respectively (Table 2). These values can be criticized since the variability among the WE contents of each individual is not only due to the position of the individual within the stage but also to different individual patterns (genetic background, etc). However, considering the problems on the initial estimates previously mentioned, it is likely that the correct estimate of the WE catabolized during the $\mathrm{CV}$ moulting is closer to 70 than $40 \mu \mathrm{gC}$ for $C$. finmarchicus and closer to 30 than $20 \mu \mathrm{g} \mathrm{C}$ for C. helgolandicus. Gatten et al. (1980) found that the amount of WE catabolized during moulting of C. helgolandicus CV ranged between 2 and $21 \mu \mathrm{gC}$ (see their Table 3). As we explained before (see 'Materials and methods'), these results are imprecise because the estimate of the WE in the CV did not correspond to the final upper value of the stage (reached just before moulting) but is an average of the WE accumulated in $\mathrm{CV}$ that were at different positions within the stage.

Hypothesis on the onset of the overwintering descent. Our results indicate that the cost of moulting by $\mathrm{CV}$, which is mainly due to gonad development, is mostly independent of feeding history, i.e. it is independent of the size or weight of the CV. This suggests that any CV has to accumulate a minimum of WE to moult to adult female. The organisms which go into diapause in deep cold waters will have to accumulate more WE than that required for gonad maturation in order to support other important energetic requirements occurring during the termination of diapause (Ingvarsdóttir et al. 1999, Jónasdóttir 1999). We propose the hypothesis that CVs that do not accumulate more than $\sim 70 \mu \mathrm{gC}$ of WE during their growth in the case of Calanus finmarchicus or $\sim 30 \mu \mathrm{gC}$ of WE in the case of C. helgolandicus will remain at the surface. During the formation of a new generation at the surface in spring, some individual CV migrate into deep waters (but also some CIV and females), whereas others remain at the surface (Irigoien 1999). In many studies, the weight values (carbon, nitrogen and lipid content) and the size of the individuals in deep waters have been shown to be higher than those measured for individuals at the surface (Hirche 1983, Durbin et al. 1995, 1997, Arashkevich et al. 1996, Heath \& Jónasdóttir 1999, Jónasdóttir 1999). The formation of the 2 populations of CV (i.e. one which had high growth rates and which were able to migrate, and another one which had low growth rates and which remained at the surface) could be the result of the heterogeneity of the food concentration in the field or to differences in the match between their growth and the phytoplankton bloom. Richardson \& Verheye (1999) showed that the variability among the growth rates measured in situ (or more exactly, the coefficient of variation) increases with the size of stages (the study was carried out on the CI to CV of a Calanus sp.) or with the size of species. Indeed, in the field in which food is patchily distributed (Dagg 1977, Cowles et al. 1993), the critical concentration $(\mathrm{Cc})$, below which growth is food limited, is higher for larger stages (Vidal 1980a, Richardson \& Verheye 1999, Rey-Rassat et al. 2002a). Therefore, the Cc of Stage CV might be less frequently encountered in the field than the $\mathrm{Cc}$ of younger stages, which would tend to increase the variability among the individual growth increments of the CV. This effect may be increased by slight differences, in the order of days, in the timing between the phytoplankton bloom and growth of Calanus.

Other hypotheses can explain the presence of 'fatter' individuals in deep waters compared to the surface, e.g. genetic or hormonal control. It is also possible that the separate populations of CV are, in fact, not derived from the same population and that they belong to different water masses. In some cases, the CV may also be lighter at the surface only because they are younger and they are still accumulating lipids at the surface. It is also possible that individuals with a lower lipid storage than our threshold value could go into overwintering and use the following years ingestion for moulting and gonad maturation. However, this does not fit with the observations of heavier individuals in the deep 
waters and with the fact that ascending CVs have higher lipid contents than females, and that the lipid content of females decreases after the ascent, probably because the lipid is used to produce eggs (Niehoff \& Hirche 1996, Irigoien et al. 1998, Niehoff et al. 1999).

Our results suggest that a threshold amount of WE could be the biochemical signal inducing the physiological responses leading to diapause. Moult controlling hormones in insects and crustaceans (i.e. ecdysones) are derived from dietary cholesterol (Lachaise et al. 1993), and although their biosynthesis pathways and functioning mechanisms are still unclear (Smith \& Sedlmeier 1990, Lachaise et al. 1993, Spaziani et al. 1999), it seems possible that the lipid storage could play a role in the regulation of these hormones.

However, the determination of this threshold may be more complicated in the field than it appears in our study. It is likely that it varies with temperature since it is a key factor in influencing metabolism. The threshold of WE below which copepodites do not go into diapause certainly depends on the temperature that is experienced when the population grows in surface waters; the higher the temperature, the lower is the threshold. Similarly, the energetic cost of developing gonads certainly varies with the temperature occurring when the CVs are ready to moult into adult after overwintering. In the case of Calanus finmarchicus, our estimate of the cost of developing gonads $(\sim 70 \mu \mathrm{g} C)$, which is also the threshold below which copepodites would remain at the surface, is relatively similar to that estimated in the field study by Jónasdóttir (1999), in which the temperature range was indeed close to that used in our study $\left(\sim 8^{\circ} \mathrm{C}\right)$. Comparable interaction between body condition and migratory behavior has recently been demonstrated by Hays et al. (2001) for Metridia pacifica, where individual variability in diel vertical migration is influenced by body condition, with those animals with larger lipid stores not needing to risk ascent to feed at the surface at night.

This study provides a first quantification of the costs of moulting and gonad maturation in Calanus helgolandicus and C. finmarchicus and provides the means to test an hypothesis at the onset of the descent vertical migration, i.e. that a threshold amount of WE could be the biochemical signal inducing the physiological responses (e.g. hormones) leading to diapause. A first step to test this hypothesis would be to determine, in relation to temperature, WEs, weight and size characteristics of CV collected at different depths, when the copepods start to migrate to deep waters.

Acknowledgements. This study was carried out as part of the Trans-Atlantic Study of Calanus finmarchicus project (TASC) and was supported financially by the Commission of the
European Community through contract MAS3-CT95-0039 (TASC) and the Plymouth Marine Laboratory. We thank S. Nival, Station Zoologique, Villefranche-sur-mer, for checking some lipid measurements.

\section{LITERATURE CITED}

Arashkevich EG, Drits AV, Timotin AG (1996) Diapause in the life cycle of Calanoides carinatus (Kroyer), (Copepoda, Calanoida). Hydrobiologia 320:197-208

Carlotti F, Nival S (1992) Moulting and mortality rates of copepods related to age within stage: experimental results. Mar Ecol Prog Ser 84:235-243

Cowles TJ, Desiderio RA, Neuer S (1993) In situ characterization of phytoplankton from vertical profiles of fluorescence emission spectra. Mar Biol 115:217-222

Dagg M (1977) Some effects of patchy food environments on copepods. Limnol Oceanogr 22:99-107

Diel S, Tande KS (1992) Does the spawning of Calanus finmarchicus in high latitudes follow a reproductive pattern? Mar Biol 113:21-31

Durbin EG, Gilman SL, Campbell RG, Durbin AG (1995) Abundance, biomass, vertical migration and estimated development rate of the copepod Calanus finmarchicus in the southern Gulf of Maine during late spring. Cont Shelf Res 15(4/5):571-591

Durbin EG, Runge JA, Campbell RG, Garrahan PR, Casas MC, Plourde S (1997) Late fall-early winter recruitment of Calanus finmarchicus on Georges Bank. Mar Ecol Prog Ser 151:103-114

Fromentin JM, Planque B (1996) Calanus and environment in the eastern North Atlantic. II. Influence of the North Atlantic Oscillation on C. finmarchicus and C. helgolandicus. Mar Ecol Prog Ser 134:111-118

Gatten RR, Sargent JR, Forsberg TEV, O'Hara SCM, Corner EDS (1980) On the nutrition and metabolism of zooplankton. XIV. Utilization of lipid by Calanus helgolandicus during maturation and reproduction. J Mar Biol Assoc UK 60:391-399

Hakanson JL (1984) The long and short term feeding condition in field-caught Calanus pacificus, as determined from the lipid content. Limnol Oceanogr 29:794-804

Hays GC, Kennedy H, Frost BW (2001) Individual variability in diel vertical migration of a marine copepod: why some individuals remain at depth when others migrate. Limnol Oceanogr 46(8):2050-2054

Heath MR, Jónasdóttir SH (1999) Distribution and abundance of overwintering Calanus finmarchicus in the FaroeShetland Channel. Fish Oceanogr 8(Suppl 1):40-60

Hirche HJ (1983) Overwintering of Calanus finmarchicus and Calanus helgolandicus. Mar Ecol Prog Ser 11:281-290

Hirche HJ (1996a) The reproductive biology of the marine copepod, Calanus finmarchicus-a review. Ophelia 44: $111-128$

Hirche HJ (1996b) Diapause in the marine copepod, Calanus finmarchicus - a review. Ophelia 44:129-143

Hygum BH, Rey C, Hansen BW, Tande K (2000) Importance of food quantity to structural growth rate and neutral lipid reserves accumulated in Calanus finmarchicus (Gunnerus). Mar Biol 136:1057-1074

Ikeda T, Mitchell AW (1982) Oxygen uptake, ammonia excretion and phosphate excretion by krill and other Antarctic zooplankton in relation to their body size and chemical composition. Mar Biol 71:283-298

Ikeda T, Torres JJ, Hernández-León S, Geiger SP (2000) Metabolism. In: Harris RP, Wiebe PH, Lenz J, Skjoldal HR, 
Huntley M (eds) Zooplankton methodology manual. Academic Press, San Diego, p 455-532

Ingvarsdóttir A, Houlihan DF, Heath MR, Hay SJ (1999) Seasonal changes in respiration rates of copepodite stage V Calanus finmarchicus (Gunnerus). Fish Oceanogr 8(Suppl 1):73-83

Irigoien X (2000) Vertical distribution and population structure of Calanus finmarchicus at station India $\left(59^{\circ} \mathrm{N}, 19^{\circ} \mathrm{W}\right)$ during the passage of the great salinity anomaly, 19711975. Deep-Sea Res Part I 47:1-26

Irigoien X, Head R, Klenke U, Niehoff B, Harris R, Hirche HJ (1998) A high frequency time series at Weathership $M$, Norwegian Sea, during the 1997 spring bloom: feeding of adult female Calanus finmarchicus. Mar Ecol Prog Ser 172: $127-137$

Jónasdóttir SH (1999) Lipid content of Calanus finmarchicus during overwintering in the Faroe-Shetland Channel. Fish Oceanogr 8(Suppl 1):61-72

Kattner G, Krause M (1987) Changes in lipids during the development of Calanus finmarchicus s.l. from copepodid I to adult. Mar Biol 96:511-518

Lachaise F, Le Roux A, Hubert M, Lafont R (1993) The molting gland of crustaceans: localization, activity, and endocrine control (a review). J Crustac Biol 13:198-234

Lopez MD (1991) Moulting and mortality depend on age and stage in naupliar Calanus pacificus: implication for development time of field cohorts. Mar Ecol Prog Ser 75:79-89

Marshall SM, Orr AP (1955) The biology of a marine copepod Calanus finmarchicus (Gunnerus). Oliver and Boyd, London

Miller CB, Morgan CA, Prahl FG, Sparrow MA (1998) Storage lipids of the copepod Calanus finmarchicus from Georges Bank and the Gulf of Maine. Limnol Oceanogr 43(3): 488-497

Niehoff B, Hirche HJ (1996) Oogenesis and gonad maturation in the copepod Calanus finmarchicus and the prediction of egg production from preserved samples. Polar Biol 16: 601-612

Niehoff B, Klenke U, Hirche HJ, Irigoien X, Head R, Harris R (1999) A high frequency time series at Weathership $M$, Norwegian Sea, during the 1997 spring bloom: the reproductive biology of Calanus finmarchicus. Mar Ecol Prog Ser 176:81-92

Plourde S, Runge JA (1993) Reproduction of the planktonic copepod Calanus finmarchicus in the Lower St. Lawrence Estuary: relation to the cycle of phytoplankton production and evidence for a Calanus pump. Mar Ecol Prog Ser 102: 217-227

Rey C, Carlotti F, Tande K, Hygum BH (1999) Egg and faecal pellet production of Calanus finmarchicus females from controlled mesocosms and in situ populations: influence of age and feeding history. Mar Ecol Prog Ser 188:133-148

Rey-Rassat C, Irigoien X, Harris R, Head R, Carlotti F (2002a) Growth and development of Calanus helgolandicus-reared in the laboratory. Mar Ecol Prog Ser 238:125-138

Editorial responsibility: Otto Kinne (Editor),

Oldendorf/Luhe, Germany
Rey-Rassat C, Irigoien X, Harris R, Head R, Carlotti F (2002b) Egg production rates of Calanus helgolandicus females reared in the laboratory: variability due to present and past feeding conditions. Mar Ecol Prog Ser 238:139-151

Richardson J, Verheye HM (1999) Growth rates of copepods in the southern Benguela upwelling system: the interplay between body size and food. Limnol Oceanogr 44(2): 382-392

Richardson K, Jónasdóttir SH, Hay SJ, Christoffersen A (1999) Calanus finmarchicus egg production and food availability in the Faroe-Shetland Channel and northern North Sea: October-March. Fish Oceanogr 8(Suppl 1):153-162

Runge JA (1984) Egg production of the marine, planktonic copepod, Calanus pacificus Brodsky: laboratory observations. J Exp Mar Biol Ecol 74:53-66

Runge JA (1987) Measurement of egg production rate of Calanus finmarchicus from preserved samples. Can J Fish Aquat Sci 44:2009-2012

Sargent JR, Falk-Petersen S (1988) The lipid biochemistry of calanoid copepods. Hydrobiologia 167/168:101-114

Sargent JR, Henderson RJ (1986) Lipids. In: Corner EDS, O'Hara SCM (eds) The biological chemistry of marine copepods. Clarendon Press, Oxford, p 59-164

Sargent JR, Gatten RR, Corner FDS, Kilvington CC (1977) On the nutrition and metabolism of zooplankton. XI. Lipid in Calanus helgolandicus grazing Biddulphia sinensis. J Mar Biol Assoc UK 57:525-533

Smith WA, Sedlmeier D (1990) Neurohormonal control of ecdysone production: comparison of insects and crustaceans. Invertebr Reprod Dev 18:77-89

Spaziani E, Mattson MP, Wang WL, McDougall HE (1999) Signaling pathways for ecdysteroid hormone synthesis in crustaceans Y-organs. Am Zool 39:496-512

Tande KS (1982) Ecological investigations on the zooplankton community of Balsfjorden, northern Norway: generation cycles, and variations in body weight and body content of carbon and nitrogen related to overwintering and reproduction in the copepod Calanus finmarchicus (Gunnerus). J Exp Mar Biol Ecol 62:129-142

Tande KS, Hopkins CCE (1981) Ecological investigations of the zooplankton community of Balsfjorden, northern Norway: the genital system in Calanus finmarchicus and the role of gonad development in overwintering strategy. Mar Biol 63:159-164

Vidal J (1980a) Physioecology of zooplankton. I. Effects of phytoplankton concentration, temperature and body size on the growth rate of Calanus pacificus and Pseudocalanus sp. Mar Biol 56:111-134

Vidal J (1980b) Physioecology of zooplankton. II. Effects of phytoplankton concentration, temperature, and body size on the development and moulting rates of Calanus pacificus and Pseudocalanus sp. Mar Biol 56:135-146

Visser AW, Jónasdóttir SH (1999) Lipids, buoyancy and the seasonal vertical migration of Calanus finmarchicus. Fish Oceanogr 8(Suppl 1):100-106

Submitted: March 21, 2001 Accepted: February 26, 2002

Proofs received from author(s): July 19, 2002 